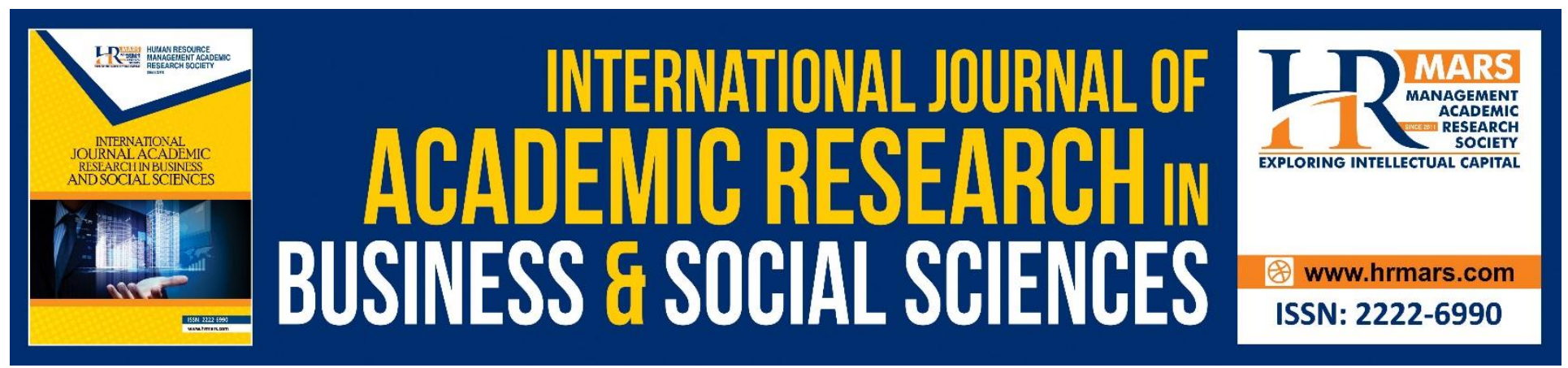

\title{
Making an Informed Decisions in a Teaching Hospital: How Medical Record System Helps
}

Nora Aslinda Mohd Amin, Saiful Farik Mat Yatin, Jafalizan Md Jali, Noor Zaidi Sahid, Shamila Mohamed Shuhidan, Siti Arpah Noordin, Wan Abd Malek Wan Abdullah

To Link this Article: http://dx.doi.org/10.6007/IJARBSS/v10-i11/8124

DOI:10.6007/IJARBSS/v10-i11/8124

Received: 03 September 2020, Revised: 01 October 2020, Accepted: 30 October 2020

Published Online: 24 November 2020

In-Text Citation: (Amin, et. al., 2020)

To Cite this Article: Amin, N. A. M., Yatin, S. F. M., Jali, J. M., Sahid, N. Z., Shuhidan, S. M., Noordin, S. A., \& Abdullah, W. A. M. W. (2020). Making an Informed Decisions in a Teaching Hospital: How Medical Record

System Helps. International Journal of Academic Research in Business and Social Sciences. 10(11), 549-564.

Copyright: (c) 2020 The Author(s)

Published by Human Resource Management Academic Research Society (www.hrmars.com)

This article is published under the Creative Commons Attribution (CC BY 4.0) license. Anyone may reproduce, distribute, translate and create derivative works of this article (for both commercial and non-commercial purposes), subject to full attribution to the original publication and authors. The full terms of this license may be seen

at: $\underline{\text { http://creativecommons.org/licences/by/4.0/legalcode }}$

Vol. 10, No. 11, 2020, Pg. 549 - 564

http://hrmars.com/index.php/pages/detail/IJARBSS

JOURNAL HOMEPAGE

Full Terms \& Conditions of access and use can be found at http://hrmars.com/index.php/pages/detail/publication-ethics 


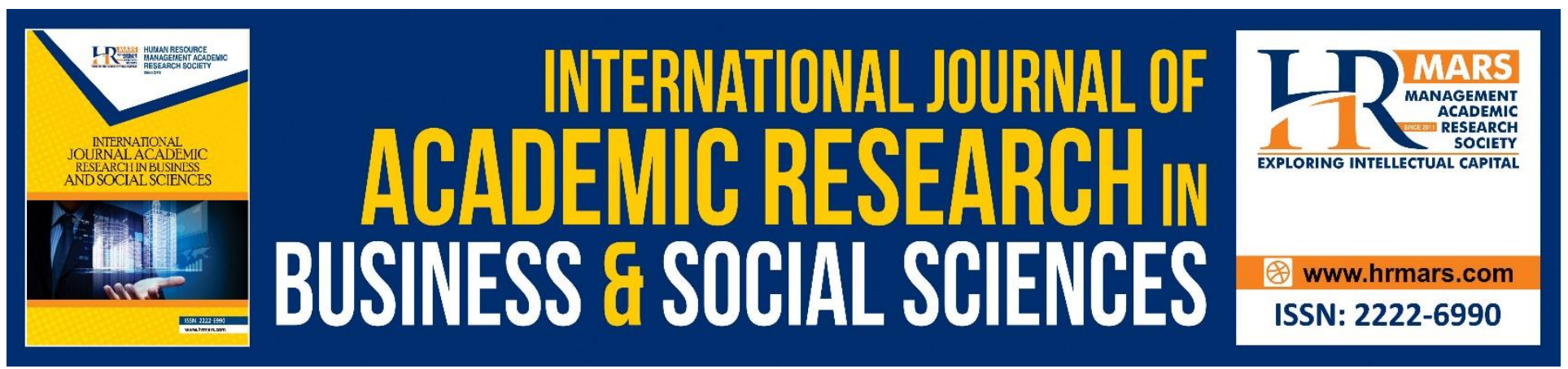

\title{
Making an Informed Decisions in a Teaching Hospital: How Medical Record System Helps
}

\author{
${ }^{1}$ Nora Aslinda Mohd Amin, 1,2Saiful Farik Mat Yatin, ${ }^{1}$ Jafalizan Md \\ Jali, Noor Zaidi Sahid, ${ }^{1}$ Shamila Mohamed Shuhidan, ${ }^{1}$ Siti Arpah \\ Noordin, ${ }^{1}$ Wan Abd Malek Wan Abdullah \\ ${ }^{1}$ Faculty of Information Management, Universiti Teknologi MARA (UiTM) Selangor, Malaysia \\ ${ }^{2}$ Members of Advanced Analytics Engineering Center (AAEC), UiTM Malaysia \\ Email: noraaslinda23@gmail.com,farik@uitm.edu.my
}

\begin{abstract}
Hospital is an institution which is sick to death or wounded person are given clinical treatment. Well prepared doctor and nurses also as a first-class facilities and equipment for valuable aset of hospital to become a good medical care industry. Medical record also form an vital part of patient's presentday and forthcoming health care. Misdiagnose a patient conditon can give serious consequences to patient which happen when medical record are inaccurate, incomplete, up-to date and reachable medical record. Aims of the paper are to classify medical record management in university hospital associated with good practice in managing records, to assess the staff skill in managing medical records appropriately and to see medical record management program contribute for quality decision making. The study applies quantitative method approach with use structured questionnaire. A technique of cluster sampling was to organise the entire hospital into nine departments (clusters). The researcher goal-directed selected 90 health staff and a records staff to contribute in this research. Researcher found that completeness physical note and nursing note of patient and also use and archive lifecycle do not associate with good practice in managing medical records. From the study, it is clear that most of the medical record officers have insight into personal skills and competencies about medical record. Researcher found that for second research question, medical record officers have the right level of staff skill to manage medical records appropriately. From the survey on decision making factor, the finding are, all factor in doing decision making are significant. Good medical record management program associated with quality of decision making. Misfiling and missing files, shortage of records staff and poor staff knowledge are the three main problems that affect the hospital in their quest to managing records effectively and making decisions. So that, researcher recommendation are to make adoption of an integrated Electronic Records Management System, more training for records staff, conducive storage and enlarge storage location, adequate records staff and more alert about security issues.
\end{abstract}


INTERNATIONAL JOURNAL OF ACADEMIC RESEARCH IN BUSINESS AND SOCIAL SCIENCES Vol. 10, No. 11, 2020, E-ISSN: 2222-6990 @ 2020 HRMARS

Keywords: Record, Medical Record, Records Management, Decision Making, Role of Medical Records

\section{Introduction}

To secure and protect patient, X-rays, specimens, medicine records and patient information, record essentially well managed to ensure any problem do not arising in the future. Good medical record practices can help hospital's administration forecast future budget for hospital needed such as medicine, facility and infrastructure. Characteristics of good medical record practices are record can be trace or found again in the facility by saving time and resources, library of medical record is restricted area for staff only and regularly transferred, archive or destroy uneeded record. Medical record is a medium for measurement of work being done by the medical and nursing staff which recorded history of patient and clinical treatment progress also become the source of information for many purposes. This paper mainly discuss about medical record function, concept, significance and challenges in handling medical record as a whole. Role of medical record management practice in improving decision making also mention and discuss in this article.

Healthcare is a complex which consist organizations, people and institution to maintain and restore physical health. Decision making in healthcare can be difficult due to its complexity, yet it is vital due to high stakes: doctors need to rapidly indicate the accurate course of action when it comes to lives of their patients, and hospital leaders must ensure delivery of superior care within limited resources while still generating sustainable proceeds. Therefore, medical record acts as an important role in the battle of medico-legal cases whether won or lost.

\section{Background Study}

Over the last few decades there is information explosion in health services. Mountain of information in health service provides a myth and certainty for public, healthcare policy-makers and importantly to patient itself. Decision making in healthcare environment basically based on scientific evidence which is known as evidence-based practice. In everyday practice, physicians and patients are working together exchange of information and sharing the decision (Malykh \& Rudetskiy, 2018). In psychology, decision making mean as intellectual process consequential in the assortment of a certainty or a path of act among numerous conceivable alternative possibilities.

Zegers (2011) stated in his analysis that patient's medical record starts out with the primary objective of recording and gathering information to support the delivery of good care, communication between healthcare workers, clinical judgement and to ensure the continuity of care. One of the most critical decisions a physician has to make based on medical information in an emergency department (ED) is whether to admit a patient or not. Admissions and readmissions are an important indicator of healthcare efficiency (Silow-Carroll, 2011). If a patient is readmitted shortly after a hospital stay, this might imply that the hospital discharged the patient without adequate care or the right diagnosis. Furthermore, current scales have shown that preventable short-term admissions can also be cut down and even eliminated if physicians have access to appropriate medical history (Ben-Assuli, Leshno \& Shabtai, 2012). 
INTERNATIONAL JOURNAL OF ACADEMIC RESEARCH IN BUSINESS AND SOCIAL SCIENCES Vol. 10, No. 11, 2020, E-ISSN: 2222-6990 @ 2020 HRMARS

Medical record life cycle instigates with creation, preservation and end with disposal. Managing recordkeeping have their own guideline and best practice develop by organization or university. Paediatric record must keep for twenty-five (25) years, obstetric record kept for twenty-one (21) year, Psychiatric record need to keep lifetime and three (3) years after death compared to other medical records which need to kept in organization's store record for seven (7) years (National Archive Act 2003).

\section{Records Management Problems}

In decision to make next treatment by the patient's personal doctor to rule out radiotherapy for their patient required medical records first to know medical history of the patient. Nevertheless, if the medical records and X-rays of the patient possibly could not be obtained, this caused, the doctor being incapable to keep on since concern of delivering the erroneous care to patient and patient life was at risk as a consequence of inaccessibility of records (Marutha, 2017).

At a university hospital in Iran, researchers recognized that most medical records in the hospital were inadequate and contradicting with the established standards. Insufficient charting was attributable to poor handwriting, lack of papers of requested information (e.g. laboratory results) and misplaced pages. Hospital staff seemed to be ignorant of the significance of medical records in management and patient treatment plan (Pourasghar, Malekafazli, Kazemi, 2008).

\section{Incompetent Staff Skills}

Record Management practices are handling by staff with inadequate knowledge or skills in management of record and record consider as not important in organisations (Tale \& Alefaio, 2011). In other way, to make sure medical record managing by skill and experience staff, organisation demanded to have records employees that have skills to manage the records that have been established in the programme of their interest (Mensah, 2011). Record keeping in health institutions had been plagued by factors such as poor staff skills, incompetent records personnel and low prioritization of records management in relation to other functions (Afolabi, 2004; Egwunyenga, 2009).

\section{Poor Decision Making}

In a situation where the organization does not value the profits of good record keeping practices, the ramifications are poor healthcare delivery, long patient waiting time, poor decisions and weak corporate memory. In the end, healthcare providers finally make-up to not concentrating certain services because the patient's history is not contained or captured in medical files (Hitler, 2013; Marutha, 2011). Healthcare institutions do not recognize an effective records management system as a key mechanism for attaining their desired goals (Acheampong, 2012). Absence of a well-functioning records management system, decision is made without detailed information (Ngoepe, 2004; Wamukoya \& Mutula, 2005).

\section{Literature Review}

\section{Record Management Program}

Ohsfeldt (2005); Shekelle, Morton \& Keeler, (2006); Thompson \& Brailer (2004) concur that correct and comprehensive hospital records direct to excellence patient care, raise efficacy of care, decrease medical faults, improve access to patient data, confidentiality of patients and quality decision making. 
Furthermore, the National Archives of Malaysia (2003) declares that the level stipulates appropriate surroundings for easy retrieve timely, precise and accessible information in a record. Furthermore, medical records must be securely taking care to preclude unauthorized retrieve, modification, destruction or elimination. An efficient management of hospital records also expedite decision making, inform future decisions, increase accountability of decision makers, produce evidence in medico-legal issues, support perpetuity of the facility and improve service delivery (Akor \& Udensi, 2013). Palmer \& Marlize (2000) viewed record see as accountability to the organization which viewed as particularly crucial governance and responsible for their actions. Financial management accountability and transparency support by good record management system. Government realization and achievement the goal significant with proper health record management, liability, administration of state properties, and safeguard of privileges of its residents as well as augmenting extraneous interactions (Kemoni \& Ngulube, 2008).

Organization recognition responsible by record manager to ensure gain the attention of decision maker know the important role of record management in the organization and need to be emphasized. To carry out official duties, employee need information to responsible professionally and successfully in understandable manner. Most importantly resources of information represent by records which also can be only dependable and officially confirmable source of facts that can assist as verification of decisions, activities and businesses in an organization (Tagbotor, Adzido \& Agbanu 2015). Northwest Territories (2002) stated that to keep track of what its member have done and what was decided, led by function of record management to guarantee employees who entangled in differ operation have the needed information and an organization creates and keeps records to make sure they know the whole operation.

Shepherd \& Yeo (2003) point out three main qualities of good records: Firstly to enhance decision making and conduct transaction in business. Secondly, to supporrt accountability and legal financial obligation. Third or lastly are to promote awareness and undertands of corporate history for cultural purpose $s$ and research. Ryan in 2010 mention that preservation is a importnt process where evidental significance of record can only occur if the substance, structure and context are conserved. Cowling (2003), organizations and individuals refer to records to study the trend of preceding actions and judgements, for example to prepare contextual information, inaugurate the presence of a precedent or to validate or disprove a statement or allegation. Record are most extremely significance for an association's authoritative capacity. An organisation needs sustained history as evidence of the way by which resources were gotten, disseminated, precise and consumed (disbursements plan). This includes expenses records, which give confirmation of how compensate and utilisation were organised, and diverse records recording economic trades. Legitimate records provide evidence of legally binding promises, compulsions and remunerations complete upon by governments' organisations or communities. They present record of disputes, for example, possessions designations, benevolent status and other legitimate and societal authorisations. They possibly will be protected as evidence for governments, court of law and distinctive parties or as the source of the professional for activity taken by organisations or communities. The quintessence of 
records in associations are for figuring and executing strategies, monitoring everyday exercises, accomplishing consistency in dynamic, offering quality support to people and accomplishing more prominent productivity (Kemoni, Ngulube and Stilwell, 2007)

Completeness of medical record is a key performance indicator to measure how eficiency level of healthcare services in the hospital (Tola, 2017). Wong (2009) stated a medical record is perfect if following items are involved: patient background, page numbers on every medical record sheet, patient facts in the record, progress note by physician, inpatient progress note by nurse, if instructed for medication record, if request for lab result and if request for radiology result. Each note in the medical record have to be dated, time $(24 \mathrm{H}$ clock) and readable. Every single entry should be signed by the one who creating the note and should be made as soon as possible after the episode to be write down (e.g. difference in clinical condition, ward inspection, observation etc) and before the appropriate team member goes off duty (Mathioudakis, 2016).

State of Montana, Montana Historical Society (2002) \& Hounsome (2001) stated factors that prominent in not achieving a Good Records Management Practices are:

- $\quad$ Records management guidelines and procedures are not complete and do not cover all area of managing records.

- $\quad$ Records manager and archivist do not have any experience and skill in record

- $\quad$ Costly in implementing and maintaining Good Records Management Practices.

- $\quad$ Resources are limited to fullfill user requirement to implement a system (legislation. Number of staff and other resource adequate or not).

Nowadays, more regulatory and legal requirement need to be fit to protect the organization in managing information that has turn into the most influential source in the accomplishment of organizations regardless of form or format, this is because information are extra crucial to organizations than ever before (Sanderson \& Ward, 2003). Tagbotor, Adzido \& Agbanu (2015) in their study found that for establish and maintaining Records Management System to prevent from lack and non compliance, oragnization must develop and follow the policy or guideline

Life cycle of record started with creation, use and lastly is disposal when achieve retention period just like living organism. Shepherd \& Yeo (2003) admits that the records life cycle is regularly use by almost every organization in managing record. This statement also support by concept records are not static but related to the biological organism subject which is record also brought to live, adolescence and aged and pass away. Hare \& McLeod (1997) claims that the formation stage is the foundation of the existence period of the record. It is the step where records and facts are primarily developed or obtained. Records management pursues to resourcefully and scientifically deal with the lifespan component (creation, capture, use, maintenance, archive or disposal) of records that are day-to-day created by means of transactions actions and dealings. This indicates that records management is grounded on the standards of day-to-day assessment and controlled maintenance or elimination of records with the common objectives of certifying rightful and governing acquiescence and company responsibility (Chinyemba \& Ngulube, 2005). 
The life cycle of record upkeep and usage comprised of important stages including distribution, active storage, security and information updating. It also includes usage and sharing of materials and evidence in the record. Due to its importance and sensitivity, it is a mandatory requirement for a secure and acceptable standard when it comes to storage environment. Whenever records are needed to be migrated across different technology platforms, evidence must be established to reflect that the information remain well looked after authentically and accurately. However, virtuous retrieve as and once looked-for should continue to be available. Tavakoli \& Jahanbakhs (2013) believes that adequate preservation of medical record is crucial in a health care provision. Medical records requisite be sustained by a organisation to provide for individual treatment as well as to fulfil other main objectives such as conforming to the legal and regulatory requirements; attain accreditation; supporting the need for research, education, and reimbursement; in addition to assisting facility administration and decision making. The length of record retention varies: depending on the categories of records sustained such as fetal monitor strips, birth records, radiology descriptions and images, laboratory informations, Master Patient Indexes and type of services such as clinics, hospitals, treatment institutions etc. Medical records preservation, management as well as its discarding or annihilation is significant deliberating matters and risk regularly connected with storeroom and space capacity. Medical records employees uphold an ongoing plan or have a procedure in circumstance to maintain and extinguish the records to evade these encounters.

Records disposal is a phase of a day to day existence sequence which alludes to the exchange of the record to an archive for safety's sake for a fix timeframe. Records likewise be shipped off the files for lasting stockpiling. In advance records may possibly be arranged they experience an examination framework. Discarding could be throughout secure preserving by moving records to the chronicles or beyond lasting devastation. Records arrive at their inert stage when their essential incentive to the association slips. The National Archives of Malaysia (2003) referenced that records are arranged by level when they had arrived at edge of their lifespan. In arranging in-dynamic records thought should be made relating the estimation of data encompasses in records. The existence phase along these lines makes to the inference that records are sustained at first for hierarchical objectives and that they might be migrated into authentic guardianship when in light of period are not, at this point into dynamic use as shown on Figure 1 beneath:-

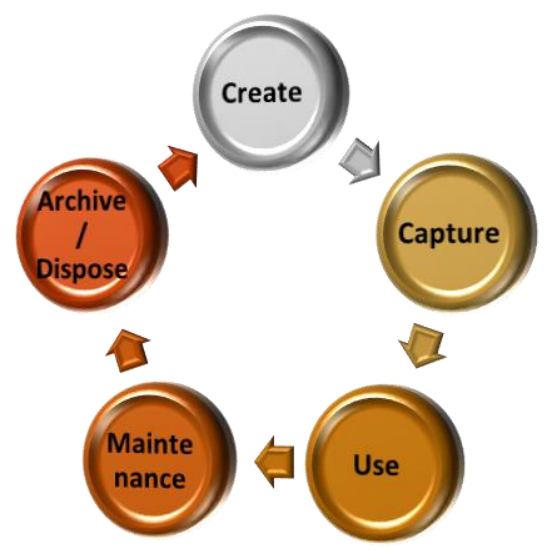

Figure 1: Lifecycle of record 
INTERNATIONAL JOURNAL OF ACADEMIC RESEARCH IN BUSINESS AND SOCIAL SCIENCES Vol. 10, No. 11, 2020, E-ISSN: 2222-6990 @ 2020 HRMARS

\section{Staff Skills}

Medical record staff must take responsibility to handle or manage record systematically, which is involve good maintenance of record through lifecycle, accessibility (have clear policy or guideline whom can be access medical record), tracking and records storage; record disposal schedule for how long its need to be keep based on discipline; permanently keep and maintain in organization; dispose with permission and follow confidential destruction or recycle. Record manager in hospital must have professional skill and competencies:

- Knowledgeable in guideline, procedure, circular, standard and best practice regarding medical record management;

- Capability in apply effective best practice in managing medical record according to the organization environment;

- Capability and understand various method or tools and techniques in medical record management;

- Knowledgeable about recent technology and software application and how to use it;

- Knowledgeable of others system in organisation such as administration, clinical support and clinical system which as a shareholder in organisation;

- Capability on doing research of others organisation experience;

- Capability in understanding the guideline, procedure, circular, policy, act to apply in organisation for give accurate and effective advice to others staff (National Records of Scotland, 2016)

Competent Record Department staffs in an organisation guarantees that records management function is conducted effectively. Employees need to be proficient with the acquaintance and talents to enhance and sustain the records management programme. The acquaintance essential should cover all the practises of records management (Chinyemba \& Ngulube, 2005). For record manager whose manage medical record need to have personal skills and competencies as following:

- Confident, believe in-self and have good communication skill in both verbally and writing;

- Capability on communicate and cooperate with other staff at all level;

- Enthusiastic and do not quickly to give up;

- Positive thinking and altitude;

- Able to complete the task through the end and brave to confront with obstacle;

- Ability to be a leader and lead the team including work as a team;

- Capability in managing the new changing of handling medical record environment (such as from manual system to electronic system);

- Influencing and good example to others staff;

- Capability talk in front of audience to share knowledge and experience;

- Analytical thinking, personal integrity and can develop wide network in workplace or another organisation;

- Always keep up to date with the latest profession (National Records of Scotland, 2016)

The knowledge and competence of healthcare providers and their assistances to the establishment, use, maintenance and conservancy of records cannot be underestimated if health care and decisions 
INTERNATIONAL JOURNAL OF ACADEMIC RESEARCH IN BUSINESS AND SOCIAL SCIENCES Vol. 10, No. 11, 2020, E-ISSN: 2222-6990 @ 2020 HRMARS

are to improve (Mensah, 2011). Those are knowledge and skill that medical record staff need in managing recordkeeping:

- Capability understand on good practice and others techniques to adapt with organisation environment;

- Capability in develop/ managing policy, procedure, guideline and circular to make it 'up to date 'in line with technological development;

- Capable in recognize which system of recordkeeping need improvisation to make it more efficient;

- Capability to make a research on medical record management and ability to recognise opportunity to improve the service;

- Positive altitude in looking a way to improve recordkeeping practices;

- Knowledgeable about recent medical record act;

- Capability in giving idea and contribution to implement latest recordkeeping best practice;

- An ability to make sure good managing medical record can lead to good decision making which improve and give benefit to the organisation;

- Capable in handling complaint and open minded;

- Capable to make sure every staff used standard guideline, circular, procedure and policy in managing recordkeeping;

- Understand and prepared the risk will be faces in managing recordkeeping, able to monitor and analyse level or value of risk;

- Capable work under pressure and deadline;

- Capability to monitor and check accuracy of information or data before given to the top management used for decision making;

- problem-solving skills;

- always alert with new information, policy, circular, standard best practice regarding record keeping (National Records of Scotland, 2016)

Record manager main role are to know about new policy, circular, procedure and guideline to develop and implement the standard that suitable with the organization operation (National Records of Scotland, 2016). Tagbotor, Adzido \& Agbanu (2015) opines that insufficiency of preparation in records management can obstruct an organization's performance. If employees do not have guiding principle on how to manage and not guided about how to handling filing systems, productivity cannot be upgraded and influence the result of decision making.

\section{Decision Making}

Decisions made at the right or opportune time leads to achieving organizational goals such as high productivity, profitability and competitive advantage whiles wrong timing of decisions sometimes waste organizational resources (Darwish, 2014). Decision making is vital for every organization that strives to mitigate risk, achieve organizational performance and improve service delivery (Tagbotor, Adzido \& Agbanu, 2015). Organizations' decision making is a complicated process that must be apprehended and interpreted entirely before it can be applied meritoriously (Nooraie, 2012). In hospitals, for a decision to be made on records generated, there is the need to interpret such information in order to inform the decision. This implies the ability to interpret available information influences the decision to make (Darwish, 2014). 
Data are correct, genuine, reliable and certified. This implies that there is no inherent limitation, free from errors and mistakes. Inaccurate information is likely to result in poor decisions likewise accurate information can also result in good decision (Ge \& Helfert, 2006). Medical record-keeping quality is element of the hospital work environment as well other features like physician-nurse relations, nurse contribution in decision making and administrative significances on quality care (Aiken, 2012). One of the most important factors in making decisions is the information or records. This is precisely to the information that having comprehensive, accurate and timely figures hasten decision making likewise scanty, inaccurate and poor timing result in making wrong decisions (Darwish, 2014). The missing part of patient record components was correlated with lower rates of AEs. Thus, misplaced record components indicate to an underestimation of AEs in record review studies. In contrast, poor quality (comprehensiveness, readable and competence) of the accessible patient information was connected with higher rates of AEs. The quality of the documented information in patient records look as if a forecaster of the quality of care (Zegers, 2011).

This refers to the timing in which decisions are made (Darwish, 2014). Decisions made at the right or opportune time leads to achieving organizational goals such as high productivity, profitability and competitive advantage. A study by Stephenson (2012) disclosed that not having enough time to decide on what to do at any particular point in time has a bearing on the quality of a decision. The author further posited that decision made under pressure could be very disastrous, as it only solves an immediate problem but could lead to a bigger problem. By detailing all pertinent medical information its mean record this evidence for upcoming reference. Keep in mind that nothing can be work as evidence without write it down properly. Continuousness in clinical notes is crucial significance to patient care as, in the present-day medical environment, many various healthcare specialists are entangled in the treatment of a single patient. Making certain that clinical notes are the latest and carry out precisely with adequate evidence will confirm that the appropriate information is prepared to all pertinent healthcare workers and will support them with capability for upcoming decisions (Mathioudakis, 2016). In a court of law, accurate medical record use as a weapon to protect the clinicians practitioner. However, the legal load of verification can depend on the particular contextual and situations in which the notes are being inspected.

Darwish, (2014) put forward that having timely information and effective records management systems expedite decision making and thus, reduce the likelihood of making poor decisions. His survey in the Iranian airports company disclosed that the practice of an efficient records management system, a simple and a functional electronic filing system increases the speed at which files or records are retrieved and subsequently, influences the speed at which clinical and administrative decisions are made in organizations. In the event where the records management systems are effective, decisions are made quicker to meet the ongoing and future needs of the organization. On the other hand, ineffective records management systems retard the speed at which decisions are made. Decisions made at the right or opportune time leads to achieving organizational goals such as high productivity, profitability and competitive advantage whiles wrong timing of decisions sometimes waste organizational resources. Many managers simply need effective records management systems and supervision to make quality judgments based on consistent indication.

However, there is no methodical guarantee that the evidence available to managers of organizations is dependable and genuine to make such decisions (Pfeffer \& Sutton, 2006). A survey conducted by 
INTERNATIONAL JOURNAL OF ACADEMIC RESEARCH IN BUSINESS AND SOCIAL SCIENCES Vol. 10, No. 11, 2020, E-ISSN: 2222-6990 @ 2020 HRMARS

Akor \& Udensi (2013) and Mampe \& Kalusopa (2012) revealed that successful records management systems ease well-timed and quality decision making, enlighten upcoming decisions and fast track service delivery. Simon Fraser University (2007) debates that records management does not only countenance an organization to operate on a daily basis, but also to fulfill its legitimate and business requests meanwhile latest news of events is presented as reference fact. Records that are supervised effectually assist sensible and proficient decision making, apprise future decisions, give indication in court case, upsurge accountability of decision makers and immediate way an competent service delivery (Akor \& Udensi, 2013; Kemoni \& Wamukoya, 2005; Mampe \& Kalusopa, 2012). With effective records management, organizations such as hospitals benefit can diminished risks for medico-legal or governing disputes by verdict and generating the appropriate proof exist in records. In effect, the hospital can be assured that there is a full disclosure of information for decision-makers to rely on in the course of carrying out their responsibilities, consequently enlightening the quality of decision making, extensive duration arrangement and delivering efficient health care to the public (Ojo, 2009). A study by Amo Justice (2016), stated that incomplete information affected the kind of decisions the units wanted to make. Countless of our attribute and security methods are risk-stratified. Comprehensive documentation with the proper coding of the problematic list will precisely imitate on the whole condition of the patient. The security procedures and quality affect payments instructed toward hospitals. As requests for surgeon-specific statistics improve, strong documentation with ICD10 may well influence capability future pay for accomplishment programs. If a surgeon under-codes a case, then the practical proportion could fall under the estimated standard of his or her team-mates (Megan, 2015).

\section{Findings}

With the 90 questionnaires distributed to one of university hospital, 90 questionnaires were returned by respondents which represented $100 \%$ of questionnaire response rate. The ages of the participants ranged from 18 to 60 years old. The majority participant age was 24 to34 years which represented (34.4\%) follow by age group between 35 to 44 years and 45 to 54 years with (18.9\%). A sizeable number (41\%) were males whiles the remaining number (49\%) were females. That is implies that a slightly higher number of females participated in the survey than males. Majority (31\%) of the respondents had attained Bachelor whiles a large number (24\%) had acquired Doctor of Philosophy (PhD). Moreover, a few (3\%) of the participants had attained secondary school. This shows that almost every staff at the hospital has acquired some form of education.

\section{Staff Skills}

From the finding, researcher found that medical record management in university hospital associated with good practice in managing records. Researcher found completeness physical note and nursing note of patient also use and archive lifecycle do not associate with good practice in managing medical records. It is clear that most of the medical record officers has insight into personal skills and competencies about medical record. They had capability on communicate and cooperate with other staff at all level; enthusiatic and do not quicly to give up, positive thinking and attitude; able to complete the task through the end and brave to confront with obstacle; ability to be a leader and lead the team including work as a team; capability in managing the new changing of handling medical record environment, including the ability to respond to changing needs and different situations such 
as develop guideline for missing medical record to prevent organization from any legal action. Not only that, medical record officers also had inluencing and good example to others staff; capability talk infront of audience to share knowledge and experience (share about do and do not in managing medical record). The important skills in record manager are they must have personal and professional integrity to make sure confidentiality of medical record preserved,; ability to develop and maintain a wide network of professional contacts and keep up to date with professional developments and actively participates within the professional community. For good analytics skills; and have marketing and promotional awareness, skills and abilities are do not significant with personal skills and competencies about medical record which is contradict with National Records of Scotland, (2016). From the study, proved medical record officers have the right level of staff skill to manage medical records appropriately.

\section{Decision Making}

Medical records generated at university hospital are correct, genuine, reliable, certified, no inherent limitation, free from errors and mistakes, detailed, accurate and timely. This will help the decision maker improve their decision making. From the survey on decision making factor, researcher found that the finding is same with the literature review which is all factor in doing decision making are significant

\section{Challenges in Managing Records and Making Decisions}

The study reveals that issues of misfiling and missing files, shortage of records staff and poor staff knowledge are the three main problems that affect the university hospital in their quest to managing records effectively and making decisions. The issue of missing files and misfiling can be setbacks for the hospital if the staffs want to retrieve files to commence daily activities or make decisions. This goes in line with the literature that for records management systems to improve decisions, issues such as missing files, misfiling, inadequate storage location, and poor staff knowledge need to be addressed adequately (Ge \& Helfert, 2006). This shows that the hospital is affected by its decisionmaking processes. Other than that, respondent also mention that staffs in university hospital with poor knowledge of using medical record and lack of knowledge using the computer. Moreover, money, budget, management support, staffs especially clinician's cooperation and understanding/ knowledge of medical record management are the challenges in handling medical records.

\section{Conclusion}

The study showed that Records Management Programme applied in the hospital that outlines by what method records are produced, captured, utilized, sustained, preserved and discarded. Furthermore, the university hospital is guided by guidelines and procedural manuals designed by Ministry of Health and National Archives of Malaysia in the management of records. Last but not least, the kind of records keeping practice adopted by the university hospital has an influence on decision accuracy, decision timeliness and decision commitment. However, poor staff knowledge, inadequate records professionals, missing files, damaged files, inadequate filing space and inadequate hardware among other challenges affect managing records at university hospital. 
INTERNATIONAL JOURNAL OF ACADEMIC RESEARCH IN BUSINESS AND SOCIAL SCIENCES Vol. 10, No. 11, 2020, E-ISSN: 2222-6990 @ 2020 HRMARS

\section{Author Biography}

Nora Aslinda Mohd Amin was a Postgraduate student from Master of Science in Records and Documents Management by Coursework (IM773) program. This program offered at the Faculty of Information Management, UiTM Selangor Branch. She has an experience working in various department related to health information such as at Jabatan Rekod Perubatan, Hospital Pakar Sultanah Fatimah (HPSF) Muar, Jabatan Kesihatan Negeri Johor, Jabatan Maklumat Kesihatan (JMK), Hospital Canselor Tuanku Muhriz (HCTM) from 2011 to Mac 2020 and Kementerian Kesihatan Malaysia (KKM) starts in April 2020. She can be contacted at noraaslinda23@gmail.com.

\section{Acknowledgement}

This article is financially supported by:

1. Faculty of Information Management, UiTM Selangor, Malaysia

2. Advanced Analytics Engineering Center (AAEC), UiTM Malaysia

\section{References}

Acheampong, E. K. (2012). Electronic Health Record System: A Survey in Ghanaian Hospitals. Journal of Health \& Medical Informatics, 03(02). doi:10.4172/scientificreports.164

Adu Freda. (2014). Assessment Of Records Management Practices Among The Administrative Staff Of University Of Education, Winneba - Kumasi (UEW-K) and Mampong (UEW-M) Campuses, (Master's Thesis, Kwame Nkrumah University of Science and Technology). Retrieved from http://ir.knust.edu.gh/bitstream/123456789/7540/1/Adu\%20Freda.pdf

Afolabi, M. (2004). Education Training Archivists and Records Managers in Africa, Annual Conference of the Society of Nigeria Archivists, 61-67. Lagos: SNA.

Ajami, S., Ketabi, S., \& Torabiyan, F. (2015). Performance improvement indicators of the Medical Records Department and Information Technology (IT) in hospitals. Pakistan Journal of Medical Sciences, 31(3), 717-720. http://doi.org/10.12669/pjms.313.8005

Akor, U.P., \& Udensi, J. (2013). An Assessment of Records Management System in establishment division of two Universities in Nigeria. International Letters of Social and Humanistic Sciences, 13, 97-109.

Aiken, L. H., Sermeus, W., Van den Heede, K., Sloane, D. M., Busse, R., McKee, M., ... Kutney-Lee, A. (2012). Patient safety, satisfaction, and quality of hospital care: cross sectional surveys of nurses and patients in 12 countries in Europe and the United States. BMJ, 344 (Mar 2012), e1717-e1717. doi:10.1136/bmj.e1717

Amo Justice. (2016). The Role Of Records Management Practices In Improving Decision Making In Public Hospitals: The Case Of Ashanti Bekwai Municipal Hospital (Master's Thesis). University of Ghana.

Ben-Assuli, O., Leshno, M., \& Shabtai, I. (2012). Using Electronic Medical Record Systems for Admission Decisions in Emergency Departments: Examining the crowdedness effect. Journal of Medical Systems, 36(6), 3795-3803. doi:10.1007/s10916-012-9852-0

Chinyemba, A., \& Ngulube, P. (2005). Managing records at higher education institutions: A case study of the University of KwaZulu-Natal, Pietermaritzburg Campus. SA Journal of Information Management, 7(1), 1-19. doi:10.4102/sajim.v7i1.250 
INTERNATIONAL JOURNAL OF ACADEMIC RESEARCH IN BUSINESS AND SOCIAL SCIENCES Vol. 10, No. 11, 2020, E-ISSN: 2222-6990 @ 2020 HRMARS

Confidentiality of Medical Records Information : Who's Responsibility? (2016, December 5). Retrieved from http://www.myhealth.gov.my/en/confidentiality-of-medical-recordsinformation-whos-responsibility/

Cowling, C. (2003). Records management manual. London: University of London.

Darwish, H., Saki, N., Sahraei, M., Zakrifar, F., \& Talebi, S. M. (2014). Effects of Automated Office Systems (automation) on improve decision making of staff managers (at the airports company of country). Journal of Educational and Management Studies, 4(3), 554-564

Egwunyenga, E. J. (2009). Record keeping in Universities: Associated problems and management options in South West Geo-Political zone of Nigeria. International Journal Education Science, 1(2), 109-113

Ge, M., \& Helfert, M. (2006). A Framework to assess decision quality using information quality dimensions. Retrieved from http://www.researchgate.net/publication/220918695_A_Framework_to_Assess_Decision_Qu ality_Using_Information_Quality_Dimensions

Hare, C., \& McLeod, L. (1997). Developing a records management programme. London: Aslib.

Hitler, D. S. (2013). The Contribution of Information Management to Administrative Decision Making in Kinondoni Municipal Council (MPA Thesis). Mzumbe University

Hounsome, C. (2001). The records management challenges of amalgamation. Municipal Monitor, June/July: 1-7.

Hospital Canselor Tuanku Muhriz UKM (HCTM). (n.d.). Retrieved from https://www.ppukm.ukm.my/language/en/

Kemoni, H. N., and Wamukoya, J. (2005). Preparing for the Management of Electronic Records at Moi University, Kenya: A case study. African Journal of Library, Archives and Information Science, 10(10), 125-138.

Kemoni, H. N., Ngulube, P., \& Stilwell, C. (2007). Public Records and Archives as Tools for Good Governance: Reflections Within the Recordkeeping Scholarly and Practitioner Communities. ESARBICA Journal: Journal of the Eastern and Southern Africa Regional Branch of the International Council on Archives, 26(1). doi:10.4314/esarjo.v26i1.31012

Kemoni, H., \& Ngulube, P. (2008). Relationship between Records Management, Public Service Delivery and the Attainment of the United Nations Millennium Development Goals in Kenya. Information Development, 24(4), 296-306. doi:10.1177/0266666908098074

Making Better Medical Decisions. (2016, September 26). Retrieved from https://www.psychologytoday.com/us/blog/modern-medicine/201609/making-bettermedical-decisions

Malaysian Medical Council. (2006). Medical Records and Medical Reports, Guideline of The Malaysian Medical Council, MMC Guideline 002/2006

Malykh, V. L., and Rudetskiy, S. V. (2018). Approaches to Medical Decision-Making Based on Big Clinical Data, Journal of Healthcare Engineering, Vol. 2018, Article ID 3917659, 10 pages, 2018. https://doi.org/10.1155/2018/3917659.

Mampe, G., and Kalusopa, P. (2012). Records Management and Service Delivery: The Case of Department of Corporate Services in the Ministry of Health. Journal of the South African Society of Archivists, 45, 2-23. 
INTERNATIONAL JOURNAL OF ACADEMIC RESEARCH IN BUSINESS AND SOCIAL SCIENCES Vol. 10, No. 11, 2020, E-ISSN: 2222-6990 @ 2020 HRMARS

Marutha, S. N. (2011). Records Management in support of Service Delivery in the Public Health Sector of the Limpopo Province in South Africa (Master of Information Science). University of South Africa. Retrieved from http://uir.unisa.ac.za/bitstream/handle/10500/5737/thesis_marutha_n.pdf?sequence=1

Marutha, N. S. (2017). A framework to embed medical records management into the healthcare service delivery in Limpopo Province of South Africa, PhD Thesis, University of South Africa

Mathioudakis, A., Rousalova, I., Gagnat, A. A., Saad, N., \& Hardavella, G. (2016). How to keep good clinical records. Breathe (Sheffield, England), 12(4), 369-373.

Megan Mcnally, MD Facs. (2015). The Importance Of Detailed Documentation in ICD-10. Bulletin of the American College of Surgeons

Mensah, M. (2011). Organizational commitment of medical records personnel at the Korle-Bu teaching hospital, Unpublished MA dissertation, University of Ghana, Legon.

National Archive Act 2003. (2003). Undang-undang Malaysia Akta 629. Retrieved July, 2018, from: http://www2.arkib.gov.my/borang/Akta_Arkib_Negara_2003.pdf

National Records of Scotland. (2016). Records Management Competency Framework July 2016, (July).

Ngoepe, M. S. (2004). Accountability, Transparency and Good Governance: the National Archives and Records Services of South Africa's role in helping Government to better Service Delivery to the South Africans. Retrieved from http://www.liasa.org.za/conferences/conferences2004/papers/LIASA_Conference_2004_Ngoe pe.pdf

Nooraie, M. (2012). Factors Influencing Strategic Decision-Making Processes. International Journal of Academic Research in Business and Social Sci, 2(7), 405-429.

Northwest Territories. (2002). What is Records Management? Records Management Bulletin, (3), 12.

Ohsfeldt, R. L. (2005). Implementation of Hospital Computerized Physician Order Entry Systems in a Rural State: Feasibility and Financial Impact. Journal of the American Medical Informatics Association, 12(1), 20-27. doi:10.1197/jamia.m1553

Ojo, T. (2009). Communication Networking: ICT and Health Information in Africa. Information Development, 22(2), 94-101

Palmer, M. (2000). Records management and accountability versus corruption, fraud and maladministration. Records Management Journal. 10. 61-72. 10.1108/EUM0000000007256

Pfeffer, J., and Sutton, R. I. (2006). Hard Facts, Dangerous Half-truths, and Total Nonsense Profiting from Evidence-Based Management. Boston, MA: Harvard Business School Press.

Pourasghar, F., Malekafzali, H., Kazemi, A. (2008). What they fill in today, may not be useful tomorrow: lessons learned from studying medical records at the Womens Hospital in Tabriz, Iran. BMC Public Health 2008;8:139.

Pohlig, C. (2014). Practice economics medical decision-making: Avoid these common coding \& documentation mistakes.

Ryan, D. (2010). What is the essence of records management? Records Management Journal, 20(1), 117-123. doi:10.1108/09565691011039889

Sanderson, M., \& Ward, S. (2003). Records management mission critical. Library and Information update, October, 1-7. Retrieved December 2, 2018 from www.cilip.org.uk 
INTERNATIONAL JOURNAL OF ACADEMIC RESEARCH IN BUSINESS AND SOCIAL SCIENCES Vol. 10, No. 11, 2020, E-ISSN: 2222-6990 @ 2020 HRMARS

Shekelle, P. G., Morton, S. C., \& Keeler, E. B. (2006). Costs and Benefits of Health Information Technology. doi:10.23970/ahrqepcerta132

Shepherd, E., and Yeo, G. (2003). Managing Records: A Handbook of Principles and Practice. Facet Publishing, London.

Silow-Carrol, S., Edwards, N. J., and Lashbrook, A. (2011). Reducing hospital readmissions: Lessons from top-performing hospitals, Care Management (17)5, 14-31.

Simon Fraser University. (2007). What's Records Management? Bumaby B.C. Canada.

State of Montana Historical Society. (2002). Performance audit report: State government records management. Legislative audit division: Helena. Retrieved March 8, 2014 from leg.state.mt.us.

Stephenson, C. B. ( 2012). What causes top management teams to make poor strategic decisions?(Doctoral Thesis). Southern Cross University, Lismore, NSW. Retrieved from http://epubs.scu.edu.au/theses/280/

Tale, S., and Alefaio, O. (2011). "Records management in developing countries: challenges and threats - towards a realistic plan", Association of Commonwealth Archivist and Records Managers. (ACARM) Newsletters, No. 37, available at: www.acarm.org/documents/issue37/37.6\%20Records\%20Management\%20in\%20Developing \%20countries\%20-\% 20challenges\%20and\%20threats.pdf.

Tagbotor, D. P., Adzido, R. Y., \& Agbanu, P. G. (2015). Analysis of Records Management and Organizational Performance. International Journal of Academic Research in Accounting, Finance and Management Sciences, 5(2). doi:10.6007/ijarafms/v5-i2/1557

Tavakoli, N., \& Jahanbakhsh, M. (2013). Investigation of retention and destruction process of medical records in the hospitals and codifying appropriate guidelines. Journal of Education and Health Promotion, 2(1), 17. doi:10.4103/2277-9531.112687

Thompson, T. G., and Brailer, D. J. (2004). The Decade of Health Information Technology: Delivering Consumer Centric and Information-rich Health Care. Washington, D.C.: U.S. Department of Health \& Human Services

Tola, K., Abebe, H., Gebremariam, Y., \& Jikamo, B. (2017). Improving Completeness of Inpatient Medical Records in Menelik II Referral Hospital, Addis Ababa, Ethiopia. Advances in Public Health, 2017, 1-5. doi:10.1155/2017/8389414

Wamukoya, J., and Mutula, S. M. (2005). E-Records Management and Governance in East and Southern Africa. Malaysian Journal of Library and Information Science, 10(2), 67-83.

West, A. F. (2002). Clinical decision-making: coping with uncertainty. Postgraduate Medical Journal, 78(920), 319-321. doi:10.1136/pmj.78.920.319.

Wong, R., Bradley, E. H., \& Hopkins, J. (2009). Medicine International, Johns Hopkins University, Baltimore, MD, USA, and Public Health, Yale School of Medicine, New Haven, CT, USA, Developing patient registration and medical records management system in Ethiopia, International Journal for Quality in Health Care; Volume 21, Number 4: pp. 253-258

Zegers, M., De Bruijne, M. C., Spreeuwenberg, P., Wagner, C., Groenewegen, P. P., \& Van der Wal, G. (2011). Quality of patient record keeping: an indicator of the quality of care? BMJ Quality \& Safety, 20(4), 314-318. doi:10.1136/bmjqs.2009.038976 